single justified or logical argument. You misrepresent the views and claims of those you disagree with, so as to more easily oppose them.

You criticize the professions (with biased inaccuracy) for ignoring public issues, and belittle them when they speak out on them. You graciously grant us the responsibility to contribute our special knowledge to the solution of such problems, but criticize us for failing to exceed the limits of such special knowledge. You insist that it's laudable for us to express ourselves singly, but dreadful to do so collectively. You sneer at the "catchy acronymic titles" of the groups concerned, though few of them are catchy, and none are acronyms. You complain that the groups "claim professional support" in a deceitful way. While the degree of professional support they have is significant and growing, their titles very specifically and accurately state their membership as limited to those members of each respective profession who are opposed to nuclear arms or war: how much more accurately could they describe themselves?

Take your own advice, Mr Editor. Put aside your pique about the professions you don't belong to; put aside your anonymity and the authority that belongs to Nature and not to you - take your courage in your hands as you exhort us to do (and as we have done) and join us on the hustings. If you can express your views coherently and support them with data, we will listen with interest and respect.

Amongst your hectic hubris, you graciously concede that "it would . . . be shocking if physicians were silent about the probable consequences of smoking". May we not also warn about the dangers of being smoked? Michael. A. Simpson

Health Sciences Center,

Temple University,

Philadelphia, Pennsylvania, USA

\section{Ab what?}

SIR - In the preamble to the first editorial in the edition of Nature dated 22 April (p.693), the word "abreact" is used. So far as I can discover the word is a term from psychoanalysis referring to the liberation of the individual from neurosis by the expression of repressed emotion. Is this what the leader article intends?

I feel it would be a pity if Nature were to start falling into the trap of employing jargon terms made meaningless by fashionable use.

It might cause some adverse reaction among the readers.

Department of Biochemistry,

Robin H. C. STRANG

University of Glasgow,

Glasgow, UK

\section{Data protection}

SIR - I read with great interest the article "Big Brother's law" (Nature 1 April, p.694) about personal data protection. I would like to add a few comments.

In the summer of 1981, the European Commission addressed a formal recommendation to European Community member states to sign and ratify the convention of the Council of Europe by the end of 1982. Up to now, only five member states have signed it.

In this recommendation, the Commission stated that it would draft a Community directive if the member states failed to sign the convention.

The socialist group in the European parliament has long pressed for a European Community directive. Indeed, in March 1982 the European parliament adopted a report of its legal committee (the report was given by Herr Sieglerschmidt, SPD) asking among other things for a Community directive for personal data control.

We believe, however, that the most important point is the control of the transnational data transfer of private companies, although you are right in the statement that the transfer of information between governmental departments is very important.

Finally, I would like to say how important it is to lobby the British members of the European parliament. The international companies are very familiar with effective lobbying of MEPs. The electorate should do the same, but in the interest of maximum protection of data on individuals.

Fritz Gautier, MEP

Braunschweig, FRG

\section{Patent sense}

SIR - The report in Nature of 29 April (p.792) of the 21 April Colloquium at the Association of the Bar of the City of New York is inaccurate in stating that a European visitor may, under European laws, derive an invention from a seminar or talk in America and appropriately apply for a patent in Europe.

European and other patent laws do not permit patents to those who derive. Typically, they require that the subject of a patent be the original work of the applicant or its predecessor in interest.

The issue of whether or not an invention is original work is different from the issue of whether or not the inventor's (original) work preceded the work of another.

Fish \& Neave,

DaVID W Plant

New York, USA

\section{Ageing controversy}

SIR - I am writing to vehemently protest about the recent News and Views article from your ageing correspondent in the 1 April issue of Nature $(296,392-393 ; 1982)$. The work of

Dr Obispo and his colleagues on "longevin", the lifespan-extending protein from carp gut is described in excruciating detail, but no mention at all is made of Dr A. Huxley's pioneering work.

It was in the obscurity of his Oxford college rooms that the re-discovery of the rejuvenating effect of raw fish viscera was made (Phil. Trans. $R$. Soc. B 240, 153-215, 1969). Furthermore, he has gone a long way in the characterization of the same protein. I am truly surprised that this work of a British scientist (who in addition comes from a very distinguished family indeed) should be overlooked in the pages of Nature. I think the reason for this is not only that the Obispo and Maunciple group has essentially unlimited funding from the Stoyte Foundation for Aging Research, but also that nowadays anything having to do with gene cloning receives immediate attention, while people like your correspondent tend to overlook standard protein chemistry work. It is sad that Dr Huxley's work has been ignored for so many years, but it is even more sad that the California group should be allowed to patent the longevin B-chain clone. The extension of human lifespan is of utmost ethical importance and should not be treated lightly; least of all in a patent office.

An Ageing Professor

Basle, Switzerland

SIR - I read the News and Views article on longevin (Nature 296, 392-393; 1982) with keen interest but think, if I may say so, that this may prove to be the swan song of geriatrical biochemistry.

JENNIFER REED

Institute for Experimental Pathology,

German Cancer Research Center,

Heidelberg, FRG

SIR - Huxley in his seminal work After Many a Summer (Chatto and Windus, 1937) was the first to draw wider attention to the research of Obispo. It is regrettable that your correspondent's otherwise excellent report on anti-senescence factors (Nature 296, 392-393; 1982) did not refer to Obispo's pioneering studies, even though these were conducted on whole carp flambé (J. Carp Sci. 1, 69; 1936).

Hauberk's results on raw carp viscera were not rediscovered until the regular visits of a member of the present shadow cabinet to Tashkent led to the realization that the famous mad ape in the local zoo was none other than the now fully evolved Lenin. Obispo himself, his procreative and creative powers equally unimpaired, will reach the age of 100 in 1984 , by which time, we can be confident, gerontology will have experienced a timely death.

London W6, UK

Richard Glendale

\section{Nuclear options}

SiR - David Fishlock should keep his journalistic innuendos (Nature 22 April, p.700) for Financial Times. He implies that my letter in Nature of 18 March (p.192) on "Electricity costs" is equivalent to flat-Earth theory, ostensibly because it cites a paper of minel as "in the press". He calls this "unpublished", but in fact Energy Policy No. 2, containing the paper, was published on 5 May, and the Financial Times was sent a copy of the page proofs before publication. In any case the scientific editor of the Financial Times was surely not unaware of the report of Sir Kelvin Spencer's committee ${ }^{2}$, which was given wide publicity after a press conference in the House of Commons on 2 February, and which quoted or paraphrased the main results of the "unpublished" paper.

I can only assume that any conclusion which does not wholeheartedly support the nuclear case is necessarily flat-Earth theory to David Fishlock, and need not be looked at any further.

J. W. JEFFERY

Department of Crystallography,

Birkbeck College,

London WCl, UK

1. The Real Cost of Nuclear Electricity in the U.K., Energy Policy, Vol. 10, No. 2, 76-100 (1982)

2. Nuctear Energy: The Real Costs: A Special Report by the Committee for the Study of the Economics of Nuclear Electricity. (Worthyvale Manor, Camelford, Cornwall). 